\title{
Inward and Outward Patriotism
}

\author{
Marianna Papastephanou ${ }^{1}$ \\ ${ }^{1}$ Department of Education, University of Cyprus, Nicosia, Cyprus \\ Correspondence: Marianna Papastephanou, Department of Education, University of Cyprus, PO Box 20537, \\ Nicosia 1678 Cyprus. E-mail: edmari@ucy.ac.cy
}

$\begin{array}{lc}\text { Received: February 27, } 2013 & \text { Accepted: March 27, } 2013 \quad \text { Online Published: April 11, } 2013 \\ \text { doi:10.5539/res.v5n2p20 } & \text { URL: http://dx.doi.org/10.5539/res.v5n2p20 }\end{array}$

\begin{abstract}
Much current philosophical discourse on patriotism either adopts an apologetic approach to patriotic sentiment or rejects it wholesale. When this discourse clings on some notion of patriotism it differentiates it from nationalism and tries to avoid the ideological baggage and socio-theoretical cost that accompanies the love of a specific collectivity: it responds to criticisms of nationalism by turning to what can be called 'inward' patriotism. However, in doing so, it typically dispenses with 'outward' patriotism. The latter is then totally conceded to aggressive and regressive nationalism. This move is accompanied with a related shift from ethnic to civic patriotism. The present article aims to expose the problems of such moves and to defend the need for more conceptual work. It retrieves a cautious outward patriotism for the sake of a fully-fledged patriotism that is compatible with, and even conducive to, cosmopolitanism. Nothing blocks this fully-fledged patriotism from being self-critical to the collectivity's treatment of outsiders. On the contrary, it is argued, outward patriotism can make patriots more aware of how their collectivity has treated otherness and more determined to pressure their collectivity to mend its ways.
\end{abstract}

Keywords: patriotism, nation, ethnos, cosmopolitanism, constitutional patriotism, communitarianism, global justice, anti-nationalism

\section{Introduction}

A relatively recent revival of debates on patriotism has influenced political philosophy to such an extent that concessions to patriotic discourse come even from the most unexpected sources. Thinkers known for their adherence to egalitarian cosmopolitanism and for their emphasis on global rather than social justice accommodate some sense of acceptable, particularist and localized affect. For instance, T. Pogge, following C. R. Beitz (Note 1), concedes two 'respects in which patriotic allegiance to political units may be desirable: it supports a sense of shared loyalty; and it allows one to see oneself as a significant contributor to a common cultural project' (Pogge, 1992, p. 58, fn 18). The patriotism of this statement is civic because it concerns allegiance to political units rather than to ethnic communities; and cultural because the focal point of one's contribution is a common cultural project. I suggest that this civic-cultural patriotism should be termed 'inward' since it does not specify how citizens react to relations with the political or national otherness that lies outside the unit.

The above citation reflects a more general tendency to avoid the older, ethnic sense of patriotism. The latter was typically construed as allegiance to a specific belonging in virtue of descent and/or culture regardless of the relation to a political configuration. Theorists of ethnic patriotism (Van den Berghe, 1987; Shaw and Wong, 1989) used to derive specific political conclusions from such allegiance and to draw much of its theoretical significance outwardly, i.e., from a relation of a national/ethnic 'We' to national/ethnic others. Yet, the bond between ethnic consociates was not thought of as inherently political but rather as biological or cultural. Thus, ethnic-cultural/biologistic patriotism was largely outward-oriented.

In this article I begin with a brief interpretation of the philosophical shift from ethnic to civic patriotism and from the outward to the inward perspective. From this springboard I criticize the lopsided current emphasis on inward patriotism and the reluctance to revisit outward patriotism and to couch it in a non-chauvinist framework. Forcing the current emphases up against their own limits confirms the need for more conceptual work on patriotism. Within a framework that is philosophical rather than sociological or historical in its epistemic grounding and operations, I suggest that patriotism should be understood in both, its inward and outward 
dimensions.

Yet, a preliminary disclaimer is necessary here. This critical re-conceptualization does not overlook nationalist pathologies. It relies on implicit assumptions (Note 2) and terminological-theoretical decisions (which cannot be argued out here for reasons of space and focus) that avoid an unsubstantiated sanitization of patriotism. These assumptions and decisions can simply be stated as follows: the term 'nationalism' is reserved for the worldview underlying the modern hyphenation of the nation and the state; the terms 'chauvinism', 'jingoism' or 'national supremacy' are employed to theorize a regressive and pernicious attachment to national locality; 'ethnic patriotism' is differentiated from both nationalism and its degenerations (chauvinism, etc); the 'ethnic' is dissociated from the 'biological' and from the exclusively 'cultural' (Note 3); and ethnic patriotism becomes a complementary aspect, not a replacement of, constitutional-political patriotism (Papastephanou, 2012b). Evidently, the 'ethnic' can (and should) also be differentiated from the national. But, because all these nuances and intricate conceptual differentiations may introduce needless technicality to an article whose aim is quite specific, they will be left aside. More generally, since the role of the above implicit assumptions and theoretical decisions in this article is only explanatory and operative, and since the argument does not stand or fall on such grounds, the above are just stated rather than deployed or defended. Therefore, my argument can be stated as follows: patriotism is Janus-faced in its requiring inward and outward optics. It is so because, as a particularist collective ethos, ideal and virtue, it concerns both belonging in a collectivity and differentiation from other collectivities. However, the outward dimension of patriotism has been downplayed and under-theorized. This philosophical neglect should be reconsidered because there are significant benefits, conceptual and normative, in recuperating the outward (other-oriented) dimension and couching it in a different framework.

\section{Patriotism or Nationalism?}

Since nationalism is often thought to cover the same ground as patriotism and to refer to similar issues and stakes, it is important to clarify why the two notions, i.e. nationalism and patriotism are not identified in this article as well as why the focus is on patriotism.

Nationalism and patriotism are connected conceptually and historically in complex ways; precisely the complexity of their connection does not allow a hasty reduction of the one to the other - much against common practice nowadays. We will touch upon that connection here so long as it helps us show the way in which nationalist disrepute reflects on patriotism and affects its academic reception. Yet, we will do so with no intention of conflating them or obfuscating their distinctiveness. There are many ways of differentiating between them, and not all of them seem entirely convincing. It is important, however, that the differentiation as such should not be overlooked. For example, Maurizio Viroli emphasizes the differences between patriotic and nationalist discourse by associating patriotism with a language of common liberty, charitable love and generosity, and nationalism with oneness, homogeneity and uniqueness (Viroli, 2003, p. 2ff). A discussion of the problems that I see in the way he differentiates between the two goes beyond the scope of this article. Suffice it here, nevertheless, to keep in mind that Viroli offers ample evidence about the very need for a differentiation in the first place. As he pertinently writes, 'the lack of a historically accurate distinction between patriotism and nationalism negatively affects even the best studies on modern nationalism' (Viroli, 2003, p. 5) and of patriotism, I would add.

Placing patriotism and nationalism in a relation of set and subset is also problematic. Mary Dietz dismisses the suggestion to think of nationalism as a distinctive species of patriotism for the following reason: it collapses 'two historically rooted forms of political practice whose differences we ignore at our own peril'. As she writes, 'the blurring of patriotism into nationalism, or even the acknowledgement of nationalism as a "species" of patriotism, reveals that we have literally lost touch with history, with a very real past in which real patriots held to a particular set of political principles and their associated practices - to a conception of citizenship that bears scant resemblance to modern nationalism' (ibid, p. 191). No matter whether Dietz's argument works at the conceptual level as smoothly as it works at the historical level, it offers us good reason to maintain a nuanced approach to such notions.

Let us then take nationalism as the worldview underlying the modern hyphenation of the nation and the state. By this I mean that nationalism is a modern term denoting allegiance to a nation-state. Either reflecting the liberal claim that the modern state functions best when drawing upon the sense of solidarity that a national identity creates; or reflecting the idea that nations have a right to self-determination and independent statehood against subjection, nationalism echoes socio-theoretical sensibilities that have been thematized in Northwestern, modern terms of nation-statehood. Unlike nationalism, patriotism conveys a less localized and temporalized sense of particularist affect as it is conceptually more related to people's feelings and acts as consociates regardless of the 
type of political configuration (e.g. be it the city-state, the nation-state, a region, etc). Thus, although it may at times coincide with nationalist concerns it does not always overlap with nationalism as it signifies a more broadly conceived allegiance than the allegiance toward a nation-state. Patriotism (Note 4) is not the specific allegiance to a nation-state, as we may reserve this for nationalism. But patriotism may concern attachment to an ethnos (Note 5) regardless of whether the latter has the status of the nation-state or belongs to a multi-national state or (in more historical applications) to city-states. Evidently, this de-placing of patriotism to whatever locale is the focus of the patriotic allegiance invites much discussion about the extent to which Benedict Anderson's (2002) assumption of a collectivity as an imagined community operates in every case (Note 6), but this is beyond the scope of this article. Suffice it here to say that it was operative in many pre-modern instances where resistance to foreign domination was voiced by communities that had not reached the status of the nation-state.

\section{Patriotism in the Light (and Shadow) of Anti-Nationalism}

That patriotism is conceptually distinct from nationalism does not mean that it is not practically conflated with the latter. This often results in patriotism being blamed for pathologies usually associated with nationalist excesses. Within much philosophy of late modernity and postmodernity (Note 7), and within the broader social imaginary, any attachment to a nation or to a nation-state is rendered suspect, and this suspicion is then expanded to any attachment to a particular collectivity felt as patria. This has the following impact on the revival of patriotism in political discourse: for many theorists of patriotism, an appropriate distance from the kindred worldview of nationalism - now largely viewed as a moral mistake (Calhoun, 2007) (Note 8) - must be taken. Thus, although there are still proponents of patriotism who take it to 'consist in loyalty to a particular nation', very many think of patriotism as 'the love of political liberty and the institutions that sustain it, or a matter of self-conception and identity' (Kleingeld, 2000, p. 316). Surely, there are also others who combine the above positions and make the term refer to all of the above or more (ibid), but the dominant tendency is to de-nationalize patriotism altogether.

It is thought that more criticality will be obtained by this de-nationalization or, perhaps even by abandoning patriotism. Identified with the national, the ethnic element of patriotism has been incriminated for lack of resistance to public policies and for blind commitment to the country's interest, right or wrong. Worse, patriotism is often identified with this lack of criticality. 'To be a patriot or to be patriotic, we are told nowadays, is to be uncritically supportive of one's government, whoever its leaders and whatever their policies. And since "patriot" has considerable commendatory force, would-be patriots are unlikely to be outspokenly critical of their government' (Ball, Farr and Hanson, 1995, p. 4). However, recent reconstructions of the conceptual history of patriotism call this present-day understanding of patriotism into question. They show that, rather than been inherent in the notion, uncritical patriotic sentiment is a distortion of it even at the historical level. For, 'to be a patriot or to be patriotic was once to have the courage to take a principled stand against one's government' (ibid). Against current sweeping generalizations, a critical-reflective patriotism emerges from a close look on Enlightenment times. 'If in eighteenth-century England the language of patriotism had become the hard currency of party rhetoric, then in America (for a time, at least) "patriotism" was the vital consciousness of a revolutionary movement, the generative force of a new people and, as Tocqueville later wrote, a "reflective" spirit of self-government' (Dietz, 1995, p. 187). Such reflective patriotism, as Dietz remarks having mapped the developments that led to such conceptual shift, 'seems no longer to be remembered as a virtue, if it is remembered at all' (ibid, p. 190).

Outside the historical level, David Miller accommodates the possibility of criticality within the very concept of nationality: to him, nationality 'makes space for the idea of loyal opposition, an individual or faction who resist prevailing policy but who can legitimately claim to speak for the same community as the government of the day' (Miller, 2003, p. 309). Thus, one of the most cherished anti-nationalist arguments that has impacted patriotism, namely, the argument that attachment to a country is a vice rather than a virtue, has been challenged. There is no compelling conceptual reason to assume that love of one's collectivity entails blind allegiance and that patriotic attachments are as such vicious or evil.

Yet, the attack on any possible meaning of nationalism, national consciousness and national identity (Note 9) has itself undergone changes that block a more nuanced thinking. Those changes have rather led to conceptual confusions, sweeping generalizations and blanket incriminations of national feeling. T. Brennan accounts for one such change as follows: 'in recent years, the attack has shifted to the related but somewhat different argument that nationalism is not evil so much as obsolete in a world run by global media networks, international agencies and multinational corporations' (Brennan, 1989, p. 2). However, since then, a backlash has taken into account more recent developments. Just indicatively and surely non-exhaustively: this backlash has shown the lasting role of nations (Calhoun, 2007) or the resilient and protean reshuffling of nationalisms (Kaldor, 2004); the 
difference between popular nationalist enthusiasm and systematic nationalist ideology (Anderson, 2002, p. 163); the country-relative character of conceptions of the nation in relation to the nation-state (Seriot, 1997, p. 42); the inadequacy of instrumentalist interpretations of the emergence of the nation-state (Brubaker, 1998, p. 274); the more complex character of the historical relation of the nation to modern politics (Smith, 2000); as well as the need for broader and more nuanced conceptions of nationalism that can also account for the routinized and daily aspects of it rather than for the vociferous ones alone [such is, for instance, Michael Billig's (2010) notion of 'banal nationalism']. The bearing all this has on our discussion here is that neither the identification of nationalism with patriotism nor the wholesale incrimination of both appears defensible within more complex elaborations on the issue of allegiance to a particular collectivity.

Nevertheless, the backlash has largely stemmed from disciplines other than philosophy and, in my view, it has, mainly for reasons of epistemic province, focused on empirical material revolving around the dipoles 'lasting role versus obsolescence' or 'modernity versus primordiality' of the nation. Thus, it has focused on the nation as a socio-historical category (often conflating it with the nation-state), and not on the normative acceptability of counterfactual possibilities inherent in a notion of ethnos that might bear different connotations from those of the nation (Note 10). For, while the nation derives from the Latin 'nascor' and has strong connotations of kinship relations, the term 'ethnos' (much against its current identification with genetic bonds) has no inherent relation with 'genus' (Papastephanou, 2012a). A counterfactual possibility of a new understanding of ethnos (contra the nation and the nation-state) is the cultivation of the ethnic affect that makes consociates sensitive to outward concerns, i.e. to how their collectivity is entangled in complex diachronic and synchronic relations with the 'outside'.

\subsection{From the Ethnic/National to the Political}

Despite the valuable work that has been done within the confines of this backlash, the general tendency of totally incriminating nationalism and transferring this incrimination to patriotism persists. Finding the origins of the nation in 'everything from the messianic chauvinism of the Hebrew Bible, the Herderian «folk» of German Romanticism, or the belligerent expansionism of Europe's late-blooming fascist powers' (Brennan, 1989, p. 1) many scholars have attacked the nation as imaginary projection altogether. As A. D. Smith puts it, for scholars, 'the ethnic version [of nationalism] remains profoundly suspect. It is widely equated with the exclusiveness of "blood" associated with the organic version of nationalism' (Smith, 2000, p. 16). Organicism and homogeneity are then seen to support a non-political concept of 'fatherland' and to replace the older conception of patria (Viroli, 2003. p. 94)

Confronting this ongoing tendency adherents to patriotism try to salvage it by jettisoning its ethnic/national predicate and by couching patriotism in purely governmental idioms. In conceding so much to their opponents, republican or liberal patriots have been led to many theoretical predicaments. Chief among them is the neglect of the fact that 'it was precisely decolonization that, unconsciously or not, [the detractors of nationalism] were also attacking' (Brennan, 1989, p. 1). Regardless of the struggle being for independence or for annexation to a larger national unity, anti-colonial and liberation movements around the world fought against imperial configurations that were far more regressive and oppressive than the nation-state for which the fighters longed. Blind anti-nationalism cannot do justice to this historical reality and in this way it becomes a subtle exculpating force in the service of sanitizing the empires.

This predicament has, amongst other things, made some thinkers realize that the notion of the nation should neither be surrendered to a disparaging, anti-nationalist discourse nor to an uncritical and even chauvinist, standard nationalist discourse. It should rather be reclaimed in terms that overcome the polemic-argumentative excesses of both nationalism and anti-nationalism. In this vein, some prominent figures of postcolonial theory have coined the term 'nationalitarianism' [Neil Lazarus (2002) and Benita Parry (2003)] to do justice to the positive sense of national feeling that exceeds the abstractly political, institutional and constitutional content of contemporary liberal takes on patriotism. This move, however, continues to concede patriotism as such to its liberal construal and refrains from reworking on its conceptual scope and content.

Philosophers in touch with the above developments either endorse the anti-nationalist tendency and reject patriotism along with nationalism wholesale; or preserve a positive sense of the nation and/or patria. As early as 1984, Alasdair MacIntyre (2003 [1984], p. 286) documented this polemical polarization between those who saw patriotism as a virtue and those who presented it with equal force as a vice. Some of the theorists who see patriotic-national affect as a virtue have recourse to by now classic theorizations of anti-colonial movements, e.g. F. Fanon's (1967); or, they derive a 'healthy' notion of nationalism from R. Rorty's neo-pragmatism (1998). For instance, the latter is more in line with K. Nielsen's (2003) combination of nationalism, cosmopolitanism, 
liberalism and socialism in a single political theory. But the most typical and disseminated reactive philosophical response to those developments has been to rescue patriotism by reducing it exclusively to political allegiance. A most prominent such position can be found in Viroli's For Love of Country, where political patriotism is understood purely inwardly as commitment to the common liberty and compassion among consociates (2003, p. 17) forming the respublica (p. 63). Within his position, there is no clear picture or detailed argument about how (or whether) such consociates think critically about the republic's treatment of those abroad.

\subsection{From the Outward to the Inward}

Nationalism and ethnic qua national patriotism had, for many years, dominated the Western imaginary in what I see as their 'outward' sense. That is, they had maintained their ideological function with an eye to some others, to those who exist outside the collectivity (Note 11). More, as E. Said (1978) had shown, following Foucault, the Western sense of solidarity went beyond the confines of ideological operations to discursive operations that 'produced' systems of knowledge about the other as oriental. In the case of nationalist supremacy, that other had been the supposedly 'inferior' other, whose disparagement made the assumed superiority of one's nation stand out (Note 12). In the case of ethnic/national patriotism, that other had typically been the 'unjust' or 'threatening' other, the real, potential or imagined enemy whose presence or actions put the patria's interests at risk. True, in some specific historical moments and concrete cases, the perception of a national other as enemy had been absolutely justified (Note 13). However, regardless of whether (and to what extent) this had been the case under some circumstances, it is important for our critical and conceptual work here that the other had typically functioned as the reference point in relation to which the national or ethnic-patriotic affect was expected to manifest itself.

Yet, this function of otherness as a reference point has remained under-theorized by friends and foes of outward patriotism/nationalism alike. National supremacist paranoia sweepingly incriminates national otherness (with all the well-known and horrific consequences) or often resorts to less vociferous though no less exclusionary operations (Said, 1978). But anti-nationalist zeal also makes theorists lose sight of the fact that relations of oppression are a good and legitimate reason to look askance at the other who oppresses a subaltern collectivity. For instance, 'sceptical readings of national liberation struggles' performed 'from the comfort of the observation tower' (Brennan, 1989, p. 6) and supplied by authors who act more as disciples rather than as constructive critics of popularized vogue operate precisely within the framework of a wholesale indictment of outward, ethnic patriotism.

But even thinkers of an older academic generation whose original work on the issue of patriotism has had a lasting influence (and their emphasis on the nation as a common project accommodates the ethnic element) confine their acknowledgement of the patriot's outward ethical debt to a passing mention. For instance, Alasdair MacIntyre counts in the patriot's moral tasks to consider 'what crimes of my nation I am bound to make reparation' (2003, p. 298) without theorizing, however, how this might be reflected in the way we conceive and approach patriotism as such. Thus, a richer and more accurate theorization of the relational variety that may connect patriots and their others is neglected. From there on, the exclusive turn to inward preoccupations (i.e. the collectivity's internal affairs) comes as no surprise.

The turn to the inward becomes manifest in many instances of influential thought on these matters. When E. Gellner sums up the 'good arguments' that can support a universalist and 'non-egoistic nationalism' (his term), the ones he selects for illustrating his point are redolent of 'ecological' culturalism (Note 14) and introvert functionalist concerns. Such are: 'the desirability of preserving cultural diversity, of a pluralistic international political system, and of the diminution of internal strains within states' (Gellner, 2004, p. 2). But even defenders of a more Janus-faced conception of the nation also leave aside any sense of outward nationalism (and equally of patriotism), probably for fear of its inauspicious historical record. Hence, only inward nationalism is detectable in C. Calhoun's following remark:

Approaches to liberal cosmopolitanism that do not take seriously the work nationalism does in the modern era and that do not work with a strong appreciation and understanding of solidarity and subjectivity, are as apt to be pernicious as progressive in actual politics. For nationalism is not only deeply imbricated in the social arrangements of the modern era, it is basic to movements to challenge and improve those social arrangements (Calhoun, 2007, p. 166).

Nationalism is thus rescued only on the grounds of its internal (within the state) social operations, whilst any outward aspect of it (e.g. socio-historically manifested in some anti-colonial liberation movements or in some nations' resistance to Hitler's march) remains largely in the dark. Hence, even when Viroli concedes en passant that historical conceptualization may be more complex than neat categorizations may ever allow and 
acknowledges that nationalism has historically inspired not only homogeneity but also struggles for freedom, he nevertheless maintains a blanket incrimination of nationalism presenting it as a force that foments exclusion and aggression in need of an antidote, of 'a formidable opponent' (Viroli, 2003, p. 8).

Most current revisions of the ideal and virtue of patriotism recast it in 'inward' terms (much in line with the above mentioned recasting of nationalism). For they make patriotism appear almost irrelevant to the relation with what lies outside the community. That is, they see patriotism as a binding force within a collectivity that regulates and coordinates the actions of its members regardless of whatever lies outside this specific collectivity and of the relational challenges that whatever lies outside may present. This bypasses the possibility of members of a political unit having as a patriotic duty not only to coordinate their actions along lines of what is owed to compatriots but also along lines of what is owed to, say, neighboring others or 'historically entangled' others (Note 15).

Hence, theories based on republicanism give patriotism the role of the 'cement' of society that motivates citizens to limit their individualism for the sake of the common Good and of fulfilling obligations to their patria and compatriots. Many such theories draw from C. Taylor's (e.g. 1996 and 1998) communitarianism. Theories based on constitutional conceptions give patriotism the role of the 'cement' of society that provides citizens with argumentative justification and binds them together in loyalty to the set of maxims and laws that meets their free, rational agreement and approval. From the German-continental persuasion, we may single out Habermas's philosophy (e.g. 1996a and 1996b). For Habermas, patriotism is constitutional in expressing an affirmative stance on the part of the members of supra- or multi-national-state configurations toward their common rules of government.

Viewed either from the prism of collective ethos (e.g. Taylor) (Note 16) or from that of public reason (e. g. Habermas), patriotism becomes, nevertheless, largely dissociated from outward concerns. I interpret this theoretical shift from the outward to the inward as a conscious effort on the part of political philosophers and social theorists to avoid the morally repugnant stance toward the other that often accompanied nationalism and to secure for their notion of patriotism the appropriate distance from 'bad' nationalism.

On the one hand, philosophers cannot dispense with patriotism altogether in favor of an abstract universalism. They wish to preserve an ideal (and the corresponding virtue) that concerns the attachment to some locality and specific collectivity as quite distinct from a more general attachment to the whole of humanity. As I see it, they are led to this because they recognize: the significance and inexorability of spatiotemporal existence (people being entities rooted in a specific place and time -regardless of frequency of global mobility); and the spatio-temporal character of an active political identity and citizenship away from pernicious dreams of global governance (Note 17). On the other hand, they probably realize (with deterring effects) that the recognition of a collectivity's ethical debt to others (a recognition that should be expected from an outward-looking patriot) makes really high demands on the self. True, the world has not yet cultivated the thoughtful handling of those demands, and such cultivation requires much educational preparation. Also, the pondering on large-scale (collective) ethico-political debts is per se an awfully complex matter in need of exceptional attention, nuance and intricate, all-round scrutiny. Furthermore, the true risks that are inherent in the patriotism that finds its meaning in mobilizing and uniting a collectivity against external threat cannot be overestimated: how does one 'know' that an 'other', a collectivity outside one's own, constitutes a real threat to the survival, freedom, values and well-being of one's collectivity and ought to be resisted? The other has, in many instances, been presented as a threat in order for the 'We' to rationalize its own desire to affirm itself by tarnishing the image of the other. Worse, the other has been presented as a threat just for the sake of rationalizing the profit-seeking collectivity's attack on, and suppression of, the other. Given all this negative historical record of collective perceptions of ethnic alterity; and given also that philosophers are entities located in specific contexts (Note 18) just as any other person; it is no wonder that many thinkers are easily led to the conclusion that any sense of outwardly conceptualized and demarcated patriotism is not only expendable but also politically dangerous.

\section{A Critique of Inflated Inward Patriotism}

Despite the difficulties attendant upon outward patriotism, the received, inward understanding of patriotism is implausible - especially so when inflated to the point of exhausting all the semantic contents of patriotism, with no further requirement of complementary notions and correctives. To explain why, this section discusses versions of civic patriotism that have, principally, been woven around introvert understandings of patriotism.

Typically traced back to the classical republicans of ancient Rome (Calhoun, 2007, p. 1), affection for a nation has been treated by contemporary civic republicans as a source of social stability and loyalty to collective purposes. It has also been promoted as a remedy to various pathologies, for example, to individualist political 
apathy. Within such discourses, patriotic passion 'is not the result of our rational consent to the principles of governance'. It is rather the result 'of a love that translates into action and service to the common good' (Knight Abowitz and Harnish, 2006, p. 658). More broadly, communitarianism takes patriotism to denote devotion to public weal. Communitarians assume that such devotion sets limits to private and self-regarding goals. For Taylor, in accounts that are redolent of structural-functionalist leanings (Taylor, 1998, pp. 192-6), patriotism is the collective ethos that secures allegiance to democratic practices and concessions of privileges for the sake of common benefit (Taylor, 1996). Within this framework, 'democracies require a relatively strong commitment on the part of their citizens' (Taylor, 1998, p. 200); 'in other words, the modern democratic state needs a healthy degree of what used to be called patriotism, a strong sense of identification with the polity, and a willingness to give of oneself for its sake' (ibid, p. 201).

The unqualified presentation of this inward patriotism as a guarantee of altruistic attitudes of wealthy and powerful citizens is implausible for the following reasons. The assumption that privileged citizens are ready to concede some of their advantages for the sake of the community's stability and public weal can be contested from a historical standpoint. In many instances, patriots united against external threat but felt no specific obligation to minimize internal inequalities when decisive pressure from trade unions or social movements was lacking. Or, patriots have not always shown the same eagerness to legality that they have shown in repelling external attacks. Heraclitus had already in the $6^{\text {th }}$ century implied this when urging his compatriots to the opposite: 'the citizens must defend the law, as they would defend the wall of the city' (Note 19). Moreover, patriotic solidarity was not evenly felt or expected by all the members of a community. Even if some social conflicts were indeed controlled through an appeal to patriotic feelings, this frequently meant an uneven compromise that secured the allegiance of the masses rather than re-stratification and egalitarian policies. The modus vivendi generated through patriotic ethos was frequently not based on equality and fairness. The doubleness of nationalist solidarity is very pertinently depicted in Calhoun's following comment: nationalism 'developed as a reflection of growing popular political participation and as a source of solidarity among citizens'. But nationalism 'was also promoted from above and used to mobilize ordinary people for war' (Calhoun, 2007, p. 7) (Note 20).

The hasty connection of inward patriotism with motivation towards altruism can also be contested from a philosophical-argumentative perspective. That patriotism may turn people on under certain circumstances does not entail that it turns them on for the right reasons and for just purposes. Justice may lead to patriotic conduct because the just citizen recognizes the legitimate claims of her compatriots and relativizes her own, narrow conception of what counts as interest. However, the opposite does not always hold: patriotism on its own, i.e. as republican devotion to one's community does not necessarily lead to justice, more specifically, to acting in just ways; for one may define the interest and politics of her community in a totally privatist sense. That an ideal might be motivationally efficacious does not entail that it is also effective at the justificatory and normative level. The truly devoted subject is not necessarily truly just. By contrast, the truly just subject may act as a truly devoted subject would be expected to act.

Given the above; and given also the extent to which patriotism had been theoretically and practically conflated with a qualitatively non-differentiated nationalism (i.e. either morally acceptable or morally repugnant); the well-known hostility to patriotism as a political virtue by some liberal and Marxist circles (O' Leary, 1998, p. 41) was not entirely unjustified. As such, the hostility indirectly proved the extent to which it was felt that patriotic stances were manipulated in order to secure the silence of the masses about inequalities and their blind support for various war operations. Instead of providing motives for excessive responsibilities and sacrifices on the part of local élites, republican patriotism often supported insular or even expansionist tendencies. Moreover, it offered legitimacy to unfair, unequal and hierarchical socio-economic systems. The viability of the state was not comprehended in the direction of egalitarianism but in that of conformity and assimilation. In a nutshell, patriotism as practice has, so far, led not to selfless attitudes but, more often than not, to the effacement of the critical self who fights oppression and acknowledges just claims.

Unfortunately, the idea that inward patriotism by definition mitigates self-interest - a misconception that leads to overrating the standard notion of patriotism - has guided not only defenders of patriotic ethos but also many of their liberal critics who may nevertheless share with them: the suspicion that under stronger demands for justice utopianism may lurk [on this they are on a par with Taylor (1998, p. 203)]; as well as a structural-functionalist account of society that downplays societal redirection and favors modus vivendi equilibrium. Yet, even the Marxist opponents of liberalism and communitarianism, those who do not share the above premises, also view patriotism from an inward perspective that emphasizes social justice and disconnects patriotism - often despite declarations - from issues of global, international justice already at the definitional level. Put differently, they 
lack the conception of outward patriotism that is relevant to such issues.

For instance, patriotism in discourses of Marxist leanings "is, in some senses, the antithesis of what civic republicans mean by "love of country." To love the United States is to "encourage dialogue, critique, dissent and social justice." It is to engage in the messiness and difficulty of a pluralistic democracy that does not currently work well for all citizens' (Knight Abowitz and Harnish, 2006, p. 673; emph mine). Despite its merits, this inward patriotism falls, at least momentarily, into the trap of structural-functionalist frameworks of sociological explanation. For, it fails to see that a more demanding patriotism has an outward dimension in the following sense: it expects patriots also to be critical of how their country responds to issues of global (not just social) justice in which it is involved; and it presses for a more radical (rather than homeostatic-recuperative) redirection of their own society regarding its relation to various others.

Familiar as they are with the stance of a broadly conceived Left to render any expression of concern for ethnicity and nationhood suspect (Note 21), so long as it refers to the patriot's feelings of shame or pride (depending on how her country fares in relation to what lies outside of it), these Marxist circles shy away from a less introvert love of country or hastily relegate its conceptual scope entirely to cosmopolitanism. But, unlike cosmopolitan ethico-political concern, which may refer to the whole or a part of cosmos regardless of how one's locality is related to it, my conception of outward patriotism refers, for instance, to the patriot's consciousness of how her country is implicated (as a wrong-doer) in the suffering of what lies outside. Or it may refer, for instance, to how her country is threatened (as a victim) by what lies outside. And surely this can be done even in less Manichean and more complex relations (i.e. beyond the dichotomy of 'wrong-doer versus victim').

The example of shame in its diverse instantiations may be useful here in order to show how outward patriotism and cosmopolitanism meet halfway without losing their distinctiveness. Love of one's country may mean high ethico-political expectations about how others are treated and shame about failures of the loved community to reach the ethico-political standards that it should be capable of. As a critical thinker, a citizen of a country that has unleashed an unjust war against another country may feel shame about this, demonstrate against the war, and demand that her country mend its ways and try to approximate a more desirable vision of how a country should be. Hers would be an outward patriotism compatible with, rather than inimical to, cosmopolitan principles. As a critical thinker, a citizen of one of the Pacific islands threatened by global warming may feel indignation about the fact that her island is endangered by the practices of other countries, strong or weak, and by their not taking appropriate measures (again, her outward patriotism is compatible with, rather than inimical to, cosmopolitan principles). But she may also feel shame as a human being for the destruction that humanity has caused to the environment (her stance is then cosmopolitan rather than patriotic of a kind). Or, she may feel shame for the WW2 Holocaust carried out by fellow human beings, even if her small locality had in no way been involved in it (this would be another instantiation of cosmopolitan engagement).

Not only is the inflated inward patriotism inoperative, but it also has subtle Eurocentric implications that seem so far to have remained unnoticed. Even when patriotism is weakened, as in the patriotic ideal that some cosmopolitan liberalists concede and that consists of an acknowledgment of the value of boundedness and some concomitant special obligations to compatriots, its inwardness allows only too loose a connection to ethico-political cosmopolitanism. At most, inward patriotism is compatible with such cosmopolitanism to the extent that inward patriotism improves society and better coordinates it with the objectives of political-economic cosmopolitanism (e.g., an affluent and well-ordered society can contribute more effectively to institutionalized global structures). But, in being so centripetal, inward patriotism cultivates a citizenship that may be quite sensitive to social justice, non-discrimination within the state and the like, but completely indifferent to, and ignorant of, how the state handles its external affairs. A typical example of this is the fact that many protests arise in western countries when their governments put the country's own environmental safety at risk but too few questions are asked when the same governments put others at risk, as in the case of 'nuclear colonialism' and 'environmental apartheid' (Linklater, 2002, p. 331) (Note 22).

By contrast, a more outward patriotism raises legitimate demands and protects the rights of a particular people without nationalist claims to superiority and expects its people to be fair to others actively. When doing so it promotes the concretization of cosmopolitan principles. Looking outward, a patriotic stance measures the quality and value of the community's conduct in the world not only by standards that the community itself sets but also by the standards that others set when appraising this conduct. Thus, on the condition of being cautious, vigilant and self-critical, outward patriotism may turn out to be less ethnocentric and self-absorbed than inward patriotism. This is because outward patriotism is by definition more relational to a broader otherness (and not just to the otherness - poorer and non-élite strata, immigrants, etc - within the political unit). It is more relational because, by definition, it takes into consideration what lies outside a particular collectiveness and is encountered 
at times as a visitor, as a neighbor, as a historical Other, as a concrete national Other, and so forth. From Said's Orientalism (1978) onwards, it has become clear that outward-oriented frameworks form the basis of efforts to understand how the historical course of a community discursively produces a variety of textualities that frame the 'we' and its 'others'. At the same time, and at a more practical and 'banal' level, outward patriotism can be more informed about the otherness outside or near the border and more attentive to its claims.

Now, are the risks of sliding into undesirable and pernicious doubles (as described in a previous section) exclusive to outward patriotic attachment? If yes, then, one might say that the neglect of outward patriotism is justified, despite the shortcomings of inward patriotism that we have just stated. If no, then there is no compelling argument in favor of such neglect. We may term this question as one of extra risks of degeneration. For instance, the assumption that republican patriotism is a far less dangerous kind of affect than nationalism reflects precisely this uneven association of degenerations risks with one particular form of affect. This assumption determines to a great extent Viroli's (2003, p. 184) proposal that societies cultivate patriotism in a sanitized republican and, in my view, totally inward form.

Civic patriotism is love for common political liberty and the institutions that support it. This kind of patriotism is inherently political (Taylor, 1998, pp. 201-2), and it may even be independent from ethnic or national identities (Kleingeld, 2000, p. 317). At first glance, the post-national character of this type of patriotism seems to secure a safe distance from the nationalist illusions of grandeur that lurk when one ponders the relation of her collectivity to the 'outside'. Based on politics and the civil society rather than on national statehood/consciousness (even if the latter plays the role of the cement of the community as in communitarianism), this patriotism appears easily reconcilable with cosmopolitanism. This is all the more so when it can prove that the political principles grounding it are indeed universal or generalizable. But if the latter is not the case (and this is a matter that cannot be settled easily, as it goes beyond the self-understanding of the patriots themselves), the patriots may end up entertaining illusions of political grandeur by assuming that their patria is closer to unshakable universal principles than the homeland of others. They have worked hard for the improvement of their internal affairs and they are proud of their accomplishments. When they rise from their introvert preoccupations and spare a glance at the global mosaic, they find in it like-minded and 'advanced' others as well as others 'who lag behind' (according to the patriots' standards). National grandeur is thus just replaced by political grandeur. This may not quite be nationalism, as it need not focus on the nation and/or the nation-state; it may just characterize the imaginary of any multi-nation-state or of any regional political configuration. Yet, it has, nevertheless, all the negative effects of nationalist supremacy. It may even entail military operations for saving others from what is viewed as their self-inflicted backwardness or for shortening their distance from universal political principles. A similar danger lurks, I believe, in the so-called 'trait patriotism' (Kleingeld, 2000, p. 319), which does not explain love for a locality/group by means of origin, belonging or political consciousness but rather by means of the traits of a place/community that inspire the patriot.

National/ethnic patriotism does not focus on the political commonwealth in which one is a citizen but on the national/ethnic group to which one belongs and which is clearly separated from other such groups (Kleingeld, 2000, p. 319; Taylor, 1998, p. 201). Let us accept this de-politicizing, rigid demarcation for the sake of deploying the following argument. The emphasis here is on the group that one feels as her own (Note 23) and not necessarily as a successful concretization of a specific political ordering or as a carrier of specific and uniquely attractive traits or properties (Kleingeld, 2000, p. 320). When the emphasis is on the 'possessive' rather than on the 'accomplished', the undesirable implication that our patria is supposedly better or superior than that of others can more easily be staved off. In simpler words, we love our group because it is our own but not because we assume that it is supposedly better (or has accomplished more) than the patria of others (Note 24). We may thus reach the subversive conclusion that, in some cases, ethnic attachment may be safer than political attachment. Then again, neither this conception of patriotism precludes the possibility that this sense of belonging may obfuscate obligations to those who are ethnically Other. Feeling committed to what is 'our own' may block awareness of a broader justice and acknowledgment of duties to other groups. This possibility is more threatening when the 'possessive' (i.e. the idea of a 'group-as-my-own') is construed as a ground for unconditionally and irrationally favoring the familiar/familial at the expense of the foreign. Therefore, patriotism of all forms (probably just like cosmopolitanism of all forms) may slide into those undesirable and dangerous doubles with which it shares borders. Parenthetically, to the extent that all these patriotisms reflect, or rely on, rigid demarcations between the ethnic (Note 25) and the civic that naturalize this distinction, they are susceptible to related criticisms as much as nationalism has been. For, 'the opposition of civic and ethnic nationalisms exerts a powerful influence over the study of nationalism, but like many typologies it obscures as much as it reveals' (Calhoun, 2007, p. 146). 
Overall, the answer to the above question about inward patriotism's extra proximity to degeneration is 'no'. Much like 'banal nationalism' which, as Billig explains (2010, p. 7), is by definition neither benign nor always pernicious, outward patriotism can slide into undesirable forms just as any other collective ideal. The conclusion is that there is no compelling argument, deriving from the fear of degeneration, in favor of neglecting outward-looking patriotism. As argued in a previous section, the neglect of outward patriotism is merely motivated by an apologetic sentimentalism; it distorts patriotic affect as it is experienced and as it has historically been manifested in mobilizing insurrection; and it closes the door to an intrinsically self-critical patriotism regarding outsiders (how they have been treated by the patria and what patria owes to them). Given all the above, such neglect is totally unjustified. Conversely, outward patriotism emerges as an affect both possible and much to be desired.

\section{Conclusion}

Let us summarize the direction of the revision of patriotism that this article has suggested. Contemporary responses to anti-nationalism deny conceptual citizenship to outward-looking patriotism and display some discomfort regarding ethnicity when reformulating patriotism. Inward, civic conceptions of patriotism are examples of efforts to purify the standard way by which the patriotic ideal has been operative within a political unit, while keeping the specter of nationalist excess away - yet often unsuccessfully and at a high cost. Inward patriotism does not always take the right direction, much as outward patriotism can easily revert to nationalist supremacy. All this concentration on the internal relation misses the significance of the external relation and the need to overcome false dilemmas of the past. Patriotism can be deployed through keeping a lookout for the specters of nationalist pathologies. Surely, to be compatible with cosmopolitanism patriotism of any kind (ethnic, civic or other) should not be supremacist, if the latter term denotes claims to superiority or to exclusive priority of one group over another. However, regrettably, this conceptual specification of particularist attachment as supremacist is inordinately extended in many debates so as to comprise even cases of commitment to a community that are not only acceptable but also laudable from a cosmopolitan point of view.

A citizen attached to a more fully-fledged patriotism does not care only about internal affairs. She also wants her country to improve at the level of inter-state relations and of inter-human relations to outsiders. Her pride about collective achievement is then not restricted to felicitous handlings of intro-state stakes and her critical energies are not just directed at the 'management' of domestic issues. She considers her collectivity capable of reaching higher standards in more extrovert conducts and puts forward concomitant expectations. At the same time, she defends her collectivity when the latter is threatened by external causes. Such causes vary from localized environmental damage originating from outside sources to predatory extra-state forces or even to overarching global structures threatening local diversity and lifeworldly heterogeneity). Attention to a patriotic consideration of what lies outside one's community can prove to be a crucial reaction to expansionist and homogenizing globalizing effects and, as the other side of inward patriotism, it is indispensable for a fully-fledged patriotism. Thus, we may imagine a patriotism that is Janus-faced in having both internal and external aspects that differ but complement, instead of opposing, one another.

This has a bearing even at the deepest conceptual and definitional level. The love of a community is a multi-faceted love referring to ethnic, cultural and political bonds to varying degrees and emphases according to circumstances. But such a love cannot be manifested only as commitment to the principle of common liberty (as in Viroli, 2003, p. 183) or to communal cultural bonds and the authenticity of the nation's story (as in MacIntyre, 2003 , p. 295). When patriotism is based solely on such principles it appears centripetal already on the definitional plane, as it limits the relational element to consociates alone. Its inwardness is evident also by the indulgent self-assurance that accompanies the notion of an achieved common liberty or cultural bond that needs little more than to be preserved and cherished. Attachment to being rather than to becoming reflects an inward-looking satisfaction with accomplished realities, i.e. with what one already is. To escape from such inwardness, patriotism needs another grounding principle: love of a community must be based on a critical-reflective and broadly relational vision of how the patria could and should be. Apart from being ever receding, this regulative patriotic ideal is dependent on a never-ending test: to fathom its approximation not just by one's own view about her community but also by the others' rational and fair expectations from it.

\section{References}

Anderson, B. (2002). Imagined Communities: reflections on the origin and spread of nationalism. London: Verso.

Ball, T., Farr, J., \& Hanson, R. (1995). Editors' Introduction. In T. Ball, J. Farr, \& R. Hanson (Eds.), Political Innovation and Conceptual Change. Cambridge: Cambridge University Press. 
Beitz, C. R. (1999). Social and Cosmopolitan Liberalism. International Affairs, 75(3), 515-529. http://dx.doi.org/10.1111/1468-2346.00091

Billig, M. (2010). Banal Nationalism. London: Sage Publications.

Brennan, T. (1989). Cosmopolitans and Celebrities. Race and Class, 31(1), 1-19. http://dx.doi.org/10.1177/030639688903100102

Brubaker, R. (1998). Myths and Misconceptions in the Study of Nationalism. In J. A. Hall, (Ed.), The State of the Nation (pp. 272-306). Cambridge: Cambridge University Press. http://dx.doi.org/10.1017/CBO9780511897559.013

Calhoun, C. (2007). Nations Matter: Culture, History, and the Cosmopolitan Dream. London and N. York: Routledge.

Dietz, M. (1995). Patriotism. In T. Ball, J. Farr, \& R. Hanson (Eds.), Political Innovation and Conceptual Change Cambridge: Cambridge University Press.

Fanon, F. (1967). The Wretched of the Earth. Harmondsworth: Penguin.

Gellner, G. (2004). Nations and Nationalism. Oxford: Blackwell.

Habermas, J. (1996a).Citizenship and National Identity. In V. B. Steenbergen (Ed.), The Condition of Citizenship. London: Sage.

Habermas, J. (1996b). Die Einbeziehung des Anderen: StudienzurPolitischenTheorie. Frankfurt a. M: Suhrkamp.

Kaldor, M. (2004). Nationalism and Globalization Nations and Nationalization, 10(1/2). 161-177. http://dx.doi.org/10.1111/j.1354-5078.2004.00161.x

Kleingeld, P. (2000). Kantian Patriotism. Philosophy and Public Affairs, 29(4) 313-341. http://dx.doi.org/10.1111/j.1088-4963.2000.00313.x

Knight Abowitz, K., \& Harnish, J. (2006). Contemporary Discourses of Citizenship. Review of Educational Research, 76(4), 653-690. http://dx.doi.org/10.3102/00346543076004653

Lazarus, N. (2002). The Politics of Postcolonial Modernism. The European Legacy, 7(6), 771-782. http://dx.doi.org/10.1080/1084877022000029055

Linklater, A. (2002). The Problem of Harm in World Politics: Implications for the Sociology of States-Systems International Affairs, 78(2), 319-338. http://dx.doi.org/10.1111/1468-2346.00253

MacIntyre, A. (2003). Is Patriotism a Virtue? In D. Matravers, \& J. Pike (Eds.), Debates in Contemporary Political Philosophy (pp. 286-300). London: Routledge and Open University.

Miller, D. (2003). In Defence of Nationality. In D. Matravers, \& J. Pike (Eds.), Debates in Contemporary Political Philosophy (pp. 301-318). London: Routledge and Open University.

Nielsen, K. (2003). Toward a Liberal Socialist Cosmopolitan Nationalism. International Journal of Philosophical Studies, 11(4), 437-463. http://dx.doi.org/10.1080/0967255032000136470

O' Leary, B. (1998). Ernest Gellner's Diagnoses of Nationalism: a critical overview, or, what is living and what is dead in Ernest Gellner's philosophy of nationalism? In J. A. Hall (Ed.), The State of the Nation (pp. 40-88). Cambridge: Cambridge University Press. http://dx.doi.org/10.1017/CBO9780511897559.003

Papastephanou, M. (2012a). Deconstructing the Ethnos-Nation Distinction. The Journal of Politics and Law, 5(4), 146-158. http://dx.doi.org/10.5539/jpl.v5n4p147

Papastephanou, M. (2012b). Thinking Differently About Cosmopolitanism: Theory, Eccentricity and a Globalized World. Boulder, USA: Paradigm.

Parry, B. (2003). Internationalism Revisited or in Praise of Internationalism. Interventions, 5(2), 299-314.

Pogge, T. (1992). Cosmopolitanism and Sovereignty. Ethics, 103(1), 48-75. Retrieved from http://dx.doi.org/10.1086/293470

Rorty, R. (1998). Achieving Our Country. Cambridge, MA: Harvard University Press.

Said, E. (1978). Orientalism: Western Representations of the Orient. London: Routledge and Kegan Paul.

Scruton, R. (2003). In Defence of the Nation. In D. Matravers, \& J. Pike (Eds.), Debates in Contemporary Political Philosophy (pp. 271-285). London: Routledge and Open University.

Sériot, P. (1997). Ethnos et demos: la construction discursive de l'identitécollective. LangageetSociété, 79, 39-51. 
November,

2011,

from

http://www.persee.fr/web/revues/home/prescript/article/lsoc_0181-4095_1997_num_79_1_2772

Shaw, R. P., \& Wong, Y. (1989). The Genetic Seeds of Warfare:evolution, nationalism, and patriotism. Boston: Unwin Hyman.

Smith, A. D. (2000). The Nation in History. Cambridge: Polity Press.

Taylor, C. (1996). Why Democracy Needs Patriotism. In J. Cohen, \& M. Nussbaum (Eds.), For Love of Country: Debating the Limits of Patriotism. Boston: Beacon.

Taylor, C. (1998).Nationalism and Modernity. In J. A. Hall (Ed.), The State of the Nation (pp. 191-218). Cambridge: Cambridge University Press. Retrieved http://dx.doi.org/10.1017/CBO9780511897559.009

Van den Berghe, P. (1987). The Ethnic Phenomenon. Westport: Greenwood Publishing Group.

Viroli, M. (2003). For Love of Country: an essay on patriotism and nationalism. Oxford: Oxford University Press.

\section{Notes}

Note 1. Pogge (1992) and Beitz (1999) are two of the most prominent proponents of egalitarian cosmopolitanism, a theory that is often deployed as oppositional to liberal patriotism. More generally, cosmopolitanism is set in stark contrast to patriotism by many contemporary thinkers (for more on this issue and on the implausibility of the cosmopolitanism versus patriotism dichotomy, see, Papastephanou, 2012b).

Note 2. For such assumptions and decisions, see Papastephanou (2012a).

Note 3. Given that the term 'ethnic' has been broadly viewed in the relevant literature as inextricable from the 'biological' and the 'cultural' the step of dissociating them requires at least a separate article. See, for instance, Papastephanou (2012a).

Note 4. My preference for patriotism here over the kindred notion of nationalism (due to the former's broader scope) may invite criticisms regarding the gender undertones of male power that can be attributed to patriotism. I deal with this etymologically elsewhere (Papastephanou, 2012b).

Note 5. Ethnos here is meant in a reformulated sense that deconstructs genetic associations. See Papastephanou (2012a).

Note 6. For this point I am indebted to an anonymous reviewer of this journal.

Note 7. There are interesting exceptions to this generalization: see, for instance, Roger Scruton (2003) and David Miller (2003).

Note 8. This is how Calhoun puts this vehement attack on nationalism: nationalism is often treated 'as a sort of error smart people will readily move beyond - or an evil good people must reject' (Calhoun, 2007, p. 7). B. Anderson also comments on being 'common for progressive, cosmopolitan intellectuals' to insist on 'the near-pathological character of nationalism' (Anderson, 2002, p. 141).

Note 9. We must not forget that these two, namely, national consciousness and national identity, are not identical, but here there is no space for exploring the intricacies of such a distinction.

Note 10. The most that has been done in the latter direction is the retrieval of the Janus-faced socio-historical function of the nation, yet, again, in terms that derive from epistemic frameworks and research priorities other than the philosophical.

Note 11. They did so even when their role as the 'cement' of society was carried out in relation to internal affairs.

Note 12. Chauvinism, jingoism, expansionism, imperialism, and many other pathologies (understood both as theoretical vices as well as rationalizations of gruesome acts of local and global impact) can be associated with such assumptions of the superiority of one's nation over those of others.

Note 13. Consider, for instance, peoples' resistance to Nazi invasions and attacks on their countries or peoples' resistance to colonial rule.

Note 14. By this term, I refer to theories which aim to prolong the viability of a culture and to protect its communal ethos against losses effected by the competitive liberal marketplace of ideas and lifestyles. Despite their importance, such theories do not go further than multiculturalism (consider here Gellner's above cited 
'desirability of preserving cultural diversity, of a pluralistic international political system') and a folklore, politically inoperative sense of culture often as a museum piece (Papastephanou, 2012b).

Note 15. By the latter term (see, Papastephanou, 2012b) I refer to others even on remote spots of the globe (e.g. colonized peoples) who have been involved in relations of power with a specific collectivity (e.g. colonial nation ruling the empire) and whose long exploitation by that collectivity has created historical moral debts of the kind that any critically minded and well-intending patriot/member of the collectivity should seriously consider if she were to strive for a vision of her collectivity as one aspiring to, and being capable of, justice.

Note 16. Taylor's accommodation of something like the outward aspect through the direction that his notion of recognition and dignity may take at times (e.g. 1998, pp. 206-8) is rather anemic regarding resistance to conquest or exploitation and ironically subverted by his insistence on a functionalist, introvert conception of a particular collectivity as a well-ordered society.

Note 17. Consider here Kant's (1992) objections to a world state and his fear of the 'soulless despotism' that may be lurking in such a vision.

Note 18. For instance, being a citizen of a powerful state that cannot be really threatened by other collectivities (at least in the commonest sense of a threat) or of a state which may have used the notion of the threatening other so as to unleash pre-emptive wars, one tends to assume that all considerations of external threats are equally pointless or hypocritical or nationalistically motivated, and are formulated as excuses for expansion.

Note 19. For my discussion of this dictum in relation to inward and outward patriotism, see (Papastephanou, 2012b).

Note 20. That this citation refers to nationalism and not to patriotism neither makes it irrelevant to the patriotic ethos of communitarianism that we are discussing here nor speaks for a conflation of nationalism and patriotism. It is relevant to Taylor's arguments because, though he maintains the distinction between the two, and in a way that reproduces the ethnic versus civic dichotomy, he nevertheless states that 'nationalism has become the most readily available motor of patriotism' (Taylor, 1998, p. 202).

Note 21. More broadly, in Viroli's terms, 'with a few laudable exceptions, socialist intellectuals have made little or no effort to construct a patriotism of the left capable of countering nationalism' (2003, p. 15). See also his discussion of Carlo Rosselli as such an exception (2003, p. 161).

Note 22. Nuclear colonialism refers to nuclear experiments taking place in the South Pacific on the part of global powers in plain indifference for the health and security of the local populations. And environmental apartheid refers to the practice of exporting dangerous material or waste to societies where environmental measures and restrictions are lower than in the West.

Note 23. Often, such an understanding of national affect involves familial metaphors and turns the nation into an extension of family relations and bonds.

Note 24. This argument works against Viroli's unqualified acceptance of the popular view that love for common ethnic and linguistic characteristics automatically encourages 'contempt and intolerance for cultural, racial and political diversity both at home and abroad' (Viroli, 2003, p. 12).

Note 25. At a more specific, scholarly level, the theoretical hostility to the ethnic may have its roots in Hans Kohn's influential work on the close relationship of nationalism to liberal and cosmopolitan Enlightenment values and should not be identified with ethnic variants (Calhoun, 2007, p. 119). 